\title{
ULUM AL-QUR'AN,SEJARAH DAN PERKEMBANGANNYA
}

\section{Pipih Nurasiah Jamil}

Ilmu Hadits (IHA)

\section{UNIVERSITAS ISLAM NEGRI SULTAN MAULANA HASANUDDIN BANTEN}

\begin{abstract}
Abstrak
Al-Qur'an adalah wahyu ilahi(kitab suci)yang diturunkan kepada Nabi Muhammad Saw.Sebagai pedoman hidup bagi umat manusia.Untuk memahami Al-Qur'an diperlukan berbagai ilmu,antara lain adalah "Ulum Al-Qur'an”.Ilmi ini mencakup pembahasan-pembahasan yang berhubungan dengan Al-Qur'an dari segi sebab turunnya,pengumpulan dan urutan-urutannya,pengetahuan tentang ayat-ayat makkiyah dan madaniyyah,Nasikh dan Mansukh dan lain-lain.Ulum Al-Qur'an dengan berbagai cabang dan macamnya tidak lahir sekaligus,tetapi melalui proses dan perkembangan yang dapat dibagi ke dalam fase periwayatan dan fase kodifikasi.Sampai saat ini telah lahir puluhan tokoh ini bidang Ulum Al-Qur'an,diantara mereka yang paling masyhur adalah jalaluddin Al Suyuthi yang menulis kitab Al itqan fi 'Ulumil Qur'an dan Al-Zarqany dengan karyanya Al Burhan fi 'Ulumil Qur'an.Kedua kitab ini selalu menjadi rujukan dalam kajian-kajian Ulumul Qur’an.
\end{abstract}

Keywords

Ulum Al-Qur'an,sejarah,perkembangannya

Al-Qur'an merupakan sumber utama ajaran Islam,dan juga merupakan pedoman hidup bagi setiap manusia.Al-Qur'an bukan sekedar memuat petunjuk tentang hubungan manusia dengan Tuhannya, tetapi juga mengatur hubungan manusia dengan sesamanya,bahkan hubungan manusia dengan alam sekitarnya (Choiruddin Hadliri:1993)Dengan demikian,untuk dapat memahami ajaran islam secara sempurna,maka langkah pertama yang harus dilakukan adalah memahami Al-Qu'an.

Al-Qur'an sebagaimana diketahui,diturunkan dalam Bahasa arab,baik lafal maupun uslubnya.Namun demikian,tidaklah berarti bahwa semua orang arab,atau orang yang mahir dalam bahasa arab,dapat memahami Al-Qur'an secara rinci.Bahkan menurut Ahmad Amin (1975)Para sahabat sendiri tidak sanggup memahami kandungan Al-Qur'an dengan hanya sekedar mendengarkannya dari Rasulullah Saw karena menurut beliau,memahami Al-Qur'an tidak cukup dengan menguasai Bahasa arab saja.

\section{A.Pengertian 'Ulumul Qur'an}


'Ulumul Qur'an berasal dari Bahasa arab yang merupakan gabungan dua kata(idhafi),yaitu “ulum” dan "Al-Qur'an”.Kata 'ulum secara etimologi adalah bentuk jamak dari kata 'ilmu,berasal dari kata 'alima-ya 'lamu-ilman'.'Ilmu merupakan bentuk masdar yang artinya pengetahuan dan pemahaman. Maksudnya pengetahuan ini sesuai dengan makna dasarnya,yaitu “Al-fahmu Wa al-idrak"(pemahaman dan pengetahuan).Kemudian pengertiannya dikembangkan pada berbagai masalah yang beragam dengan standar ilmiah.Kata 'ilm juga berarti "idrak al-syai'i bi haqiqatih"(mengetahui dengan sebenarnya). ${ }^{1}$

Al-Qur'an secara bahasa berasal dari bahasa Arab Qara'a-yaqra'u-qur'an yang merupakan isim masdar yaitu artinya bacaan.Menurut sebagian ulama berpendapat bahwa walaupun kata Al-Qur'an adalah masdar(bacaan), namun Al-Qur'an bermakna maf'ul (yang dibaca).Al-Qur'an merupakan wahyu Allah SWT yang diturunkan kepada Nabi Muhammad SAW sebagai mukjizat yang di dalamnya terkandung bacaan dan isi yang menarik untuk dijadikan studi sehingga melahirkan berbagai macam pengetahuan diantaranya adalah 'Ulumul Qur'an.

Menurut para ulama Ushul,ulama Fiqh,dan ulama Bahasa,Al-Qur'an adalah kalam Allah yang diturunkan kepada Nabi Muhammad SAW,yang lafadzh-lafadzhnya mengandung mukjizat,membacanya mempunyai nilai ibadah,yang diturunkan secara mutawatir,dan ditulis pada mushaf,mulai dari surat Al-Fatihah sampai surat An-Nas.

Gabungan kata 'Ulum dengan kata Al-Qur'an memperlihatkan adanya penjelasan tentang jenis-jenis ilmu pengetahuan yang berhubungan dengan Al-Qur'an;ilmu yang bersangkutan dengan pembelaan tentang keberadaan Al-Qur'an dan permasalahannya;berkenaan dengan proses hukum yang terkandung di dalamnya;berkenaan dengan penjelasan bentuk mufradat dan lafal Al-Qur'an.Al-Qur'an sebagai way of life tentunya memahami dinamika kehidupan,kemasyarakatan,hukum-hukum pidana dan sebagainya.

Abdurrahman mengemukakan bahwa 'Ulumul Qur'an mempunyai arti yaitu sebagai idlofi dan istilah.Secara idlofi kata "'Ulum”diidlofahkan kepada kata “Qur'an"maka mempunyai pengertian yang sangat luas sekali,yaitu segala ilmu yang relevansinya dengan Al-Qur'an. ${ }^{2}$ Pengertian 'Ulumul Qur'an secara istilah memiliki definisi yang berbeda-beda.Hal ini disebabkan pada fokus masing-masing keilmuan dari para ahli.Dan berdasarkan pengertian secara etimologis dan istilah yang telah dipaparkan maka 'Ulumul Qur'an memiliki makna ganda yaitu makna idhafi dan makna 'alam(nama diri),yang bisa dilihat pada paparan berikut: ${ }^{3}$

\footnotetext{
1Badrudin,"Ulumul Qur'an",Hal.1,Kota Serang

${ }^{2}$ Acep Hermawan,'Ulumul Qur'an Ilmu untuk Memahami Wahyu,(PT Remaja Rosdakarya:Bandung,2013),hlm.1-2.

${ }^{3}$ Az-Zarqani,'Abd Al-Adhim,Manahil al-Irfan fi ‘Ulumul al-Qur’an,(Dar al-Fikr:Beirut,tth.),jilid I,hlm.23.
} 
a.Makna idhafi

Penggabungan kata 'Ulum dengan kata Al-Qur'an menunjukkan arti yang luas meliputi semua unsur yang ada dalam Al-Qur'an itu sendiri yang meliputi ilmu-ilmu diniyah dan ilmu-ilmu kauniyah, inilah yang dinamakan makna idhafi.Hal ini memiliki potensi ilmu pengetahuan yang berhubungan dengan Al-Qur'an,ilmu yang bersangkutan dengan pembelaan tentang keberadaan Al-Qur'an dan permasalahannya,berkenaan dengan proses hukum yang terkandung di dalamnya,berkenaan dengan penjelasan bentuk mufradat lafal Al-Qur'an,Al-Qur'an sebagai pandangan hidup dalam menjalani dinamika kehidupan,hukum-hukum dan sebagainya.

I Ilmu pengetahuan yang berkaitan dengan hal tersebut semua bersumber pada Al-Quran dan sebagai salah satu metode untuk mengetahui kemukjizatan Al-Qur'an,seperti ilmu-ilmu tafsir,tajwid,nasikh-

mansukh,fiqh,tauhid,fara'id, tata Bahasa dan lain-lain.

b.Makna'Alam(Metodologi Kodifikasi)

Definisi ‘Ulumul Qur’an ditinjau dari makna 'alam adalah suatu ilmu yang membahas Al-Qur’an yang berkaitan dengan tujuan diturunkan,upaya pengumpulan bacaan,penafsiran,nasikh-mansukh,asbab-an-nuzul,ayarayat makkiyah dan madaniyah.

‘Ulumul Qur’an dibagi 2 yaitu;Makna idhafi dan makna 'alam

=Makna idhafi;

=Makna 'alam

1.Ilmu tafsir

1.IImu tafsir

2.IImu Qiroat

2.IImu Qiroat

3.IImu rosmil Utsmani

3.IImu Rosmil Utsmani

4.IImu I'jazil Qur'an

4.Ilmu I'jazil Qur'an

5.Ilmu I'rabil Qur'an

5.Ilmu I'rabil Qur'an

6.IImu Asbabin Nuzul

6.IImu Asbabin nuzul

7.IImu Astronomi

7.Ilmu Nasikh-Mansukh

8.IImu Hulum

8.Ilmu Ghoribil Qur'an

9.Ilmu Alam

9.'Ulumuddin 
11.IImu sosiologi

12.IImu Kimia dan lainnya.

\section{B.Sejarah Perkembangan 'Ulumul Qur’an}

Munculnya ‘Ulumul Qur’an merupakan bagian yang penting dalam mengetahui dan memahami Al-Qur'an yang harus diaplikasikan dalam kehidupan sehari-hari.'Ulumul Qur'an sebagai pengetahuan tentang Al-Qur'an fokus pada dua hal yaitu kajian yang berkaitan dengan materi-materi yang terdapat dalam Al-Qur'an seperti kajian tafsir Al-Qur'an;dan kajian yang berkenaan dengan materi-materi seputar Al-Qur'an tetapi lingkupnya di luar materi dalam Al-Qur'an seperti kajian tentang asbab an-nuzul.

Sejarah perkembangan 'Ulumul Qur'an tidak terlepas waktu kapan Al-Qur'an diturunkan pertama kali sampai dengan bagaimana Al-Qur'an menjadi sebuah mushaf.Perkembangan 'Ulumul Qur'an secara umum tidak ada yang tahu persis kapan istilah 'Ulumul Quran pertama kali diperkenalkan dan menjadi sebuah disiplin ilmu.Namun menurut beberapa ahli bahwa istilah ‘Ulumul Qur'an pertama kali diperkenalkan oleh Ibn AlMarzuben(wafat $309 \mathrm{H}$ ).

Perkembangan 'Ulumul Qur’an dikelompokan menjadi fase-fase sebagai berikut:

1.'Ulumul Qur'an pada masa Rasulullah SAW

Embrio awal 'Ulumul Qur'an pada masa ini berupa penafsiran ayat Al-Qur'an langsung dari Rasulullah SAW kepada para sahabat, begitu pula dengan antusias para sahabat dalam bertanya tentang makna suatu ayat,menghafalkan dan mempelajari hukum-hukumnya.

a.Rasulullah SAW menafsirkan kepada sahabat beberapa ayat.

Dari Uqbah bin Amir ia berkata:"aku pernah mendengar Rasulullah SAW berkata di atas mimbar,"Dan siapkan untuk menghadapi mereka kekuatan yang kamu sanggupi(Anfal:60),ingatlah bahwa kekuatan di sini adalah memanah"(HR Muslim).

b.Antusiasme sahabat dalam menghafal dan mempelajari Al-Qur'an.

Diriwayatkan dari Abu 'Abdurrahman as-Sulami,ia mengatakan:”Mereka yang membacakan Al-Qur'an kepada kami,seperti Utsman bin 'Affan dan 'Abdullah bin Mas'ud serta yang lain menceritakan, bahwa mereka bila belajar dari Nabi sepuluh ayat mereka tidak melanjutkannya,sebelum mengamalkan ilmu dan amal yang ada di dalamnya,mereka berkata 'kami mempelajari Al-Qur'an berikut ilmu dan amalnya sekaligus."

c.Larangan Rasulullah SAW untuk menulis selain Al-Qur'an,sebagai upaya menjaga kemurnian Al-Qur'an.

Dari Abu Sa'ad al-Khudri,bahwa Rasulullah SAW bersabda:"Janganlah kamu tulis dari aku;barang siapa menuliskan tentang aku selain Al-Qur'an,hendaklah dihapus.Dan ceritakan apa yang dariku,dan itu tiada halangan baginya,dan barang siapa sengaja berdusta atas namaku,ia akan menempati tempatnya di api neraka."(HR Muslim). 


\section{2.'Ulumul Qur'an pada masa Khalifah}

Pada masa khalifah,tahapan perkembangan awal(embrio)'Ulumul qur'an mulai berkembang pesat,diantaranya dengan kebijakan-kebijakan para khalifah sebagaimana berikut:

a.Khalifah Abu Bakar:dengan kebijakan pengumpulan(penulisan Al-Qur'an yang pertama yang diprakarsai oleh 'Umar bin Khottob dan dipegang oleh Zaid bin Tsabit.

b.Kekhalifahan Utsman Ra;dengan kebijakan menyatukan kaum muslimin pada satu mushaf,dan hal itupun terlaksana.Mushaf itu disebut mushaf Imam.Salinan-salinan mushaf ini juga dikirimkan ke beberapa provinsi.Penulisan mushaf tersebut dinamakan ar-Rosmul 'Usmani yaitu dinisbahkan kepada Usman,dan ini dianggap sebagai permulaan dari ilmu Rasmil Qur’an.

c.Kekhalifahan Ali Ra:dengan kebijakan perintahnya kepada Abu 'Aswad Ad-Du'ali meletakkan kaidah-kaidah nahwu,cara pengucapan yang tepat dan baku dan memberikan ketentuan harakat pada qur'an.ini juga disebut sebagai permulaan Ilmu I’rabil Qur'an.

3.'Ulumul Qur'an Masa Sahabat dan Tabi'in

a.Peranan Sahabat dalam penafsiran Al-Qur'an dan Tokoh-tokohnya

Para sahabat senantiasa melanjutkan usaha mereka dalam menyampaikan makna-makna Al-Qur'an dan penafsiran ayat-ayat yang berbeda diantara mereka, sesuai dengan kemampuan mereka yang berbeda-beda dalam memahami dan karena adanya perbedaan lama dan tidaknya mereka hidup bersama Rasulullah SAW, hal demikian diteruskan oleh murid-murid mereka, yaitu para tabi'in.

Diantaranya para Musafir yang termashur dari pada sahabat adalah:

1)Empat orang khalifah(Abu Bakar,'Umar,'Utsman dan 'Ali)

2)Ibnu Mas'ud

3)Ibnu 'Abbas,

4)Ubai bin Ka'ab,

5) Zaid bin Tsabit,

6)Abu Musa al-asy'ari dan

7)'Abdullah bin Zubair.

b.Peranan Tabi'in dalam penafsiran Al-Qur'an dan tokoh-tokohnya 
2)Murid Ubai bin Ka'ab ,di Madinah:Zaid bin Aslam,abul Aliyah,dan Muhammad bin Ka'b al-Qurazi.

3).Abdullah bin Mas'ud di Iraq yang terkenal :'Alqamah bin Qais, Masruq al Aswad bin Yazid, 'Amir as Sya'bi,Hasan Al-Basyri dan Qatadah bin Di'amah as-Sadusi.Dan yang diriwayatkan mereka itu semua meliputi ilmu tafsir,ilmu Gharibil Qur'an,ilmu Asbabun Nuzul,ilmu Makki Wal madani dan ilmu Nasikh dan Mansukh,tetapi semua ini tetap didasarkan pada riwayat dengan cara didiktekan.

\section{C.Kesimpulan}

Mengenai para tabi'in, diantara mereka ada satu kelompok terkenal yang mengambil ilmu ini dari para sahabat disamping mereka sendiri bersungguh-sungguh atau melakukan ijtihad dalam menafsirkan ayat.Yang terkenal di antara mereka,masing-masing sebagai berikut:

1)Murid Ibnu Abbas di Mekah yang terkenal ialah,Sa'id bin ubair,Mujahid,'iKrimah bekas sahaya (maula)Ibnu Abbas, Tawus bin Kisan al-Yamani dan 'Ata'bin abu Rabah. 
'Ulum Al-Qur'an adalah beberapa pembahasan yang terkait dengan Al-Qur'an dari segi:tempat, waktu dan sebab turunnya wahyu,lafal dan uslub bahasanya,kesusasteraan (Balaghah)-nya, penulisannya,pengumpulannya,bacaannya, naskh-mansukhnya,tafsirnya dan hal-hal lain yang terkait dengan Al-Qur'an.

'Ulum al-Quran yang terdiri dari berbagai macam dan cabangnya tidak lahir sekaligus,melainkan melalui proses perkembangan yang dapat dibagi ke dalam fase-fase:(1)fase periwayatan,mulai zaman

Rasulullah SAW hingga awal abad ke-2 (2)fase lahirnya cabang-cabang 'ulum al-Qur'an dan kodifikasinya, mulai abad ke-2 hingga abad ke-5 dan (3)fase kondifikasi 'ulum al-Qur'an sebagai suatu ilmu yang mencakup berbagai ilmu Al-Qur'an,yaitu sejak abad ke-5 hingga saat ini.

Hingga saat ini telah lahir puluhan tokoh di bidang 'ulum al-Qur'an, diantara mereka yang paling termashur adalah Jalil al-Din al-Sayuti pengarang kitab al-Itqan fiy 'ulum al-Qur'an dan al-Zarqasyi pengarang kitab al-Burhan fiy ulum al-Qur'an.Kedua kitab ini masih ada hingga sekarang dan menjadi rujukan bagi kajian-kajian 'ulum al-Qur'an.

\section{D.Daftar Pustaka}

Dr.H.Badrudin,M.Ag.”Ulumul Qur’an”,Hal.1,Kota Serang

Acep Hermawan,'Ulumul Qur'an Ilmu untuk Memahami Wahyu,(PT Remaja Rosdakarya:Bandung,2013),hlm.1-2

Az-Zarqani,’Abd Al-Adhim,Manahil al-Irfan fi ‘Ulumul al-Qur’an,(Dar al-Fikr:Beirut,tth.),jilid I,hlm.23.

.http://myrealblo.blogspot.co.id/2015/11/ulumul-quran-dan-sejarahnya.html

http://majlisilmuquran.blogspot.co.id/2012/07/sejarah-perkembangan-ulumul-quran.html 